\title{
The Type 1 Inositol 1,4,5-Trisphosphate Receptor Gene Is Altered in the opisthotonos Mouse
}

\author{
Valerie A. Street, ${ }^{1}$ Martha M. Bosma, ${ }^{1}$ Vasiliki P. Demas, ${ }^{1}$ Melissa R. Regan, ${ }^{2}$ Doras D. Lin, ${ }^{2}$ \\ Linda C. Robinson, ${ }^{1}$ William S. Agnew, ${ }^{2}$ and Bruce L Tempel ${ }^{1}$ \\ ${ }^{1}$ Departments of Otolaryngology and Pharmacology, University of Washington School of Medicine, Seattle, Washington \\ 98195, and Geriatric Research Education and Clinic Center, Veterans Affairs Puget Sound Health Care System, Seattle, \\ Washington 98108, and '2Department of Physiology, The Johns Hopkins University School of Medicine, Baltimore, \\ Maryland 21205
}

The opisthotonos (opt) mutation arose spontaneously in a $\mathrm{C} 57 \mathrm{BL} / \mathrm{Ks}-\mathrm{db}^{2 \mathrm{~J}}$ colony and is the only known, naturally occurring allele of opt. This mutant mouse was first identified based on its ataxic and convulsive phenotype. Genetic and molecular data presented here demonstrate that the type 1 inositol 1,4,5trisphosphate receptor $\left(\mathrm{IP}_{3} \mathrm{R} 1\right)$ protein, which serves as an $\mathrm{IP}_{3}$-gated channel to release calcium from intracellular stores, is altered in the opt mutant. $A$ genomic deletion in the $I_{3} R 1$ gene removes two exons from the $I P_{3} R 1$ mRNA but does not interrupt the translational reading frame. The altered protein is predicted to have lost several modulatory sites and is present at markedly reduced levels in opt homozygotes. Nonetheless, a strong calcium release from intracellular stores can be elicited in cerebellar Purkinje neurons treated with the metabotropic glutamate receptor (mGluR) agonist quisqualate (QA). QA activates Group I mGluRs linked to GTP-binding proteins that stimulate phospholipase $C$ and subsequent production of the intracellular messenger $\mathrm{IP}_{3}$, leading to calcium mobilization via the $\mathrm{IP}_{3} \mathrm{R} 1$ protein. The calcium response in opt homozygotes shows less attenuation to repeated QA application than in control littermates. These data suggest that the convulsions and ataxia observed in opt mice may be caused by the physiological dysregulation of a functional $I_{3} R 1$ protein.

Key words: opisthotonos; seizures; genomic deletion; Purkinje neurons; inositol 1,4,5-trisphosphate receptor; metabotropic glutamate receptor; quisqualate; mouse chromosome 6; alternative splicing
The autosomal recessive opisthotonos (opt) mutant is a singlegene mouse mutation displaying epileptic-like behaviors. Homozygote opt pups are generally smaller than their littermates, and they never acquire normal locomotor abilities. At $\sim 14 \mathrm{~d}$ postnatal (P14), opt homozygotes begin to display visible seizures. The seizure intensity and duration can range from subtle leg and body tremors lasting 2-3 sec to marked tonic-clonic convulsions in which the pup flips from side to side with a stiffly arched head, tail, and back, with the event lasting up to $30 \mathrm{sec}$. After a prolonged episode, the pup will lie panting, gripping the bedding or a littermate. The seizure intensity and frequency are progressive (Street et al., 1996), a feature of some human epilepsies. Older pups may demonstrate severe convulsions every 5-10 min. The seizures can occur spontaneously or in response to handling or agitation by a littermate. Although the pups do seem to nurse normally, they die by 3-4 weeks of age. Classical genetic techniques were used to localize opt to distal chromosome 6 approximately 6 centimorgans $(\mathrm{cM})$ telomeric

Received Aug. 28, 1996; revised Oct. 21, 1996; accepted Nov. 5, 1996.

This work was supported by grants from National Institutes of Health (B.LT. W.S.A.), the Veterans Administration (B.LT.), and The Esther A. and Joseph Klingenstein Foundation (B.LT.). Much of this work was performed at the Seattle division of the Veterans Affairs Puget Sound Health Care System. We thank T. Noda and E. Steingrimsson for sharing unpublished data; T. C. Sudhof for the rat $\mathrm{IP}_{3} \mathrm{R} 1$ cDNA; E. Rubel for use of a calcium imaging system; S. Bendahhou, M. Emerick, E. Lachica, E. Levy-Lahad, S. Matthews, P. Poorkaj, and L. Zirpel for technical advice and assistance; and W. Moody, S. Mount, N. Nathanson, P. Poorkaj, and G. Schellenberg for comments on this manuscript.

Correspondence should be addressed to Bruce L Tempel, The V. M. Bloedel Hearing Research Center, Box 357923, University of Washington School of Medicine, Seattle, WA 98195.

Copyright (C) 1997 Society for Neuroscience $0270-6474 / 97 / 170635-11 \$ 05.00 / 0$ to the mouse mutant Microphthalmia-white $\left(M i^{\mathrm{wh}}\right)$ (Lane, 1972). Although three voltage-gated potassium channel genes are in this region (Lock et al., 1994), molecular genetic studies that refined the position of opt eliminated the potassium channel genes as candidates for the opt mutation (Street et al., 1995).

The type 1 inositol 1,4,5-trisphosphate receptor $\left(\mathrm{IP}_{3} \mathrm{R} 1\right)$ gene locus (Itpr1) is also located on the distal portion of mouse chromosome 6 (Furuichi et al., 1993) in the vicinity of opt. The $\mathrm{IP}_{3} \mathrm{R} 1$ protein binds the intracellular second messenger $\mathrm{IP}_{3}$, which is generated by phospholipase C-mediated hydrolysis of phosphatidylinositol 4,5-bisphosphate (Berridge, 1993). Ligand binding triggers the efflux of calcium from intracellular stores, suggesting that $\mathrm{IP}_{3} \mathrm{R} 1$ is both a receptor for $\mathrm{IP}_{3}$ and a calcium channel. Recently, a targeted disruption of the $\mathrm{IP}_{3} \mathrm{R} 1$ gene was shown to exhibit a phenotype similar to that of opt (Matsumoto et al., 1996). In this report, we demonstrate tight genetic linkage between opt and Itpr1 and define a genomic deletion that alters the $\mathrm{IP}_{3} \mathrm{R} 1$ protein in opt mice.

\section{MATERIALS AND METHODS}

Genetic mapping. To establish the intersubspecific intercross segregating for opt, CAST/Ei-+/+ males were mated to C57BL/Ks-+/opt females. F1 hybrids carrying opt were intercrossed. Fifty-six F2 opt/opt mice were collected. Tail DNA was isolated, and microsatellite analysis was performed as described previously (Street et al., 1995). Segregation of $\mathrm{IP}_{3} \mathrm{R} 1$ in the 56 DNAs was followed by a PCR-based approach using the primer pair 5'-TGCATAGCTGCCCCTAGG-3' and 5'-TTCCTGTGATACTTTGCACCC-3' (annealing temperature of $59^{\circ} \mathrm{C}$ ), which amplify a 126 base pair (bp) product from the $3^{\prime}$ untranslated region of the $\mathrm{IP}_{3} \mathrm{R} 1$ gene. The CAST/Ei-+/+ PCR product was cleaved by BsaAI to generate a 22 
and 104 bp restriction fragment, whereas the C57BL/Ks-opt/opt amplification product lacked the $B s a \mathrm{AI}$ restriction endonuclease site. Statistical analysis of the intersubspecific intercross was performed using Map Manager (Manly, 1993).

The opt colony is maintained by crossing $M i^{\text {wh }} / o p t$ heterozygotes, allowing the genotype of nonrecombinant progeny to be predicted by coat color. The interstrain restriction fragment length variation (RFLV) was detected using Southern blot hybridization analysis (Street et al., 1995) on $B g l$ I-restricted liver DNAs with a ${ }^{32} \mathrm{P}$-labeled 276 bp fragment derived from PCR primers 5'-GCTGTTTCTCGTTGCTAATGG-3' and 5'GAGATGACACTGACTGGTCAGC-3'. The probability of heterozygosity was calculated (contact authors for details) using the generationmatrix method (Green, 1981).

Northern analysis. Total brain RNA was isolated by guanidine isothiocyanate extraction (Chomczynski and Sacchi, 1987). Twenty micrograms of total brain RNA were electrophoresed at $0.83 \mathrm{~V} / \mathrm{cM}$ for $21 \mathrm{hr}$, blotted, and hybridized with the ${ }^{32} \mathrm{P}$-labeled open reading frame (ORF) of the rat $\mathrm{IP}_{3} \mathrm{R} 1$ homolog (Mignery et al., 1990), in modified Church Gilbert buffer $\left[0.34 \mathrm{M} \mathrm{Na}_{2} \mathrm{HPO}_{4}\right.$ heptahydrate, $\mathrm{pH}$ 7.2, 7.0\% SDS, 0.001 M EDTA, and $1.0 \%$ BSA (Fraction V)] at $62^{\circ} \mathrm{C}$ and washed the next day in $0.04 \mathrm{M}$ $\mathrm{Na}_{2} \mathrm{HPO}_{4}, 0.001 \mathrm{M}$ EDTA, and $1.0 \%$ SDS at $62^{\circ} \mathrm{C}$.

Reverse transcription (RT)-PCR analysis. RT-PCR was performed according to the manufacturer's (Boehringer Mannheim, Indianapolis, IN) specifications on $0.2 \mu \mathrm{g}$ of total RNA with an annealing temperature of $60^{\circ} \mathrm{C}$. $11 \mathrm{~F} / 12 \mathrm{R}$ RT-PCR products were analyzed by Southern blot hybridization using the ${ }^{32} \mathrm{P}$-labeled type 3 opt $\mathrm{RT}$-PCR product (see Fig. $3 \mathrm{C}$ ). RT-PCR products were subcloned with the pGEM-T Vector System (Promega, Madison, WI) and sequenced using fluorescent dyedeoxy terminator chemistry (Applied Biosystems, Foster City, CA). Five subclones representing four different sequences were isolated from the opt $11 \mathrm{~F} / 12 \mathrm{R}$ RT-PCR products, whereas one subclone was isolated from the $M i^{\text {wh }}$ RT-PCR amplification.

Western analysis. Microsomes were prepared from frozen mouse cerebella by Potter-Elvejhem homogenization in ice-cold buffer $(40 \mathrm{ml} / \mathrm{g}$ tissue) of $50 \mathrm{mM} \mathrm{NaH}_{2} \mathrm{PO}_{4}, \mathrm{pH} 7.3,50 \mathrm{mM} \mathrm{KCl}, 1.0 \mathrm{mM}$ EDTA, $15 \%$ (w/v) sucrose, $10 \mu \mathrm{g} / \mathrm{ml}$ aprotinin, $1.0 \mu \mathrm{g} / \mathrm{ml}$ leupeptin, and $100 \mu \mathrm{M}$ phenylmethylsulfonyl fluoride. The homogenate was centrifuged at $5000 \times g$ for $6 \mathrm{~min}$ at $4^{\circ} \mathrm{C}$, and the pellet was resuspended in the original volume and recentrifuged. The two supernatants were combined and centrifuged at $>100,000 \times g$ for $1 \mathrm{hr}$ at $4^{\circ} \mathrm{C}$, and the resulting pellet was washed in sucrose-free buffer and recentrifuged for $30 \mathrm{~min}$. The final pellet was resuspended in $100 \mu \mathrm{l}$ of sucrose-free buffer/30 mg pellet and homogenized with a Dounce homogenizer. Microsomal membrane proteins (50 $\mu \mathrm{g}$ protein/lane for antibody SP-3A, $8 \mu \mathrm{g}$ protein/lane for SP-2A) were separated by SDS-PAGE on a $3-15 \%$ gradient gel and transferred to nitrocellulose (Schleicher and Schuell, Keene, NH). The $\mathrm{IP}_{3} \mathrm{R} 1$ protein was visualized with affinity-purified rabbit polyclonal antisera (SP-3A at 1:250 dilution, SP-2A at 1:1000 dilution), horseradish peroxidaseconjugated goat anti-rabbit secondary antibody (Cappel, Organon Teknika, Durham, NC), and the ECL detection system (Amersham, Arlington Heights, IL). Protein expression levels were quantified by means of ${ }^{125}$ I-labeled Protein A $(1 \mu \mathrm{Ci} / \mathrm{ml})$ (Amersham) in place of the secondary antibody, a Fujix Bas 1000 Phosphorimager, and accompanying MacBAS v2.2 software.

Genomic structure analysis. B6/CBAF1J-+/+ (Stratagene 946304; Stratagene, La Jolla, CA) and opt homozygote (Stratagene) mouse genomic libraries ( $\lambda$ FIX II) were screened with the $M i^{\text {wh }} 11 \mathrm{~F} / 12 \mathrm{R}$ amplification product (see Fig. $3 C$ ), and exon D (see Fig. $5 A$ ). Restricted $\lambda$ phage insert DNAs were subcloned into the pBlueScript SK vector (Stratagene) and sequenced. Five PCR primer pairs (see $* 1-* 5$ in Fig. $5 A$ ) were developed from this sequence and used to confirm the extent of the genomic deletion in opt DNA: *1 primers (5'-AGTGATCCTTCCAGCTCG-3' and 5'CCAATGATGAGAATTTGC-3' ${ }^{\prime}$ generate a 172 bp product from intron 1 ; *2 primers (5'-CCATTGGAAAGCACAGATGC-3' and 5'-CTTTTGAT CTGTGTATCTCG-3') generate a 176 bp product from intron $1 ;{ }^{*} 3$ primers (5'-GGAAACATCAGACCTTCAGG-3' and 5'-GGTCCTCCTGGTGATAGTGG-3') amplify a 73 bp product from exon B; *4 primers $\left(5^{\prime}\right.$ GGATCTAGTTCCACAAGCAGG-3' and 5'-TGCCTCCTTCCAGAAGTGC-3') generate a 165 bp product from exon $\mathrm{C}$; and $* 5$ primers (5'-GCTGAGCCTTGGTCTCAGG-3' and 5'-CGTAGTTACAGAGCCTACG-3') generate a 269 bp product from intron 3. PCR was performed as described previously (Street et al., 1995), with an annealing temperature of $55^{\circ} \mathrm{C}$ for primer pair 1 and $60^{\circ} \mathrm{C}$ for primer pairs $2-5$. The deletion was also apparent from Southern blot hybridization analysis on NsiI-restricted liver DNAs that were probed with a ${ }^{32} \mathrm{P}$-labeled $3.4 \mathrm{~kb} N$ siI genomic B6/CBA-+/+ DNA fragment.

Purified $\lambda$ DNA was used as a template for expand PCR. Expand PCR with primers $1 \mathrm{~F} / 6 \mathrm{R}$ and $7 \mathrm{~F} / 8 \mathrm{R}$ was used to establish or confirm distances in introns 1 and 3, respectively. The exact size of intron $3(>8 \mathrm{~kb})$ was not determined, because no single wild-type phage clone was isolated that spanned from exon $\mathrm{C}$ to $4 \mathrm{~F} / 5 \mathrm{R}$ sequence. Expand PCR was performed according to the manufacturer's (Boehringer Mannheim) specifications, with the following sequences: $1 \mathrm{~F}$ (see Fig. 5B); 6R (5'-CACAGTATGGACATAATGGC-3'); 7F (5'-CACCACTGCTTGGAGATGG-3'); and 8R (5'-GTTTCCCAAGTCGCTGGTG-3').

To identify a fragment containing aberrant $o p t$ genomic DNA, oligonucleotides $1 \mathrm{~F}$ and $7 \mathrm{~F}$, which flanked the altered area, were hybridized to panels of restricted $\mathrm{B} 6 / \mathrm{CBA}-+/+$ and opt homozygote $\lambda$ phage insert DNAs. $1 \mathrm{~F}$ and $7 \mathrm{~F}$ hybridized to the same size $3.0 \mathrm{~kb} X b a \mathrm{I}$ fragment in $o p t$ DNA, whereas $1 \mathrm{~F}$ detected a $1.6 \mathrm{~kb}$ wild-type $X b a \mathrm{I}$ band. Both $X b a \mathrm{I}$ fragments were sequenced and aligned, which revealed that they diverged 298 bp $3^{\prime}$ of exon A (see Fig. 3B). For the analysis, oligonucleotides $1 \mathrm{~F}$ and $7 \mathrm{~F}$ were end-labeled with $\left[\gamma^{-32} \mathrm{P}\right]$ ATP and hybridized in $6 \times \mathrm{SSC}, 20$ $\mathrm{mM} \mathrm{Na}_{2} \mathrm{HPO}_{4}$ heptahydrate, $\mathrm{pH} 7.0,2 \times$ Denhardt's solution, $0.05 \%$ $\mathrm{Na}_{4} \mathrm{P}_{2} 0_{7}$ decahydrate, $0.1 \%$ SDS, $0.1 \mathrm{mg} / \mathrm{ml}$ salmon sperm DNA at $55^{\circ} \mathrm{C}$ for $16 \mathrm{hr}$, and then washed in $6 \times \mathrm{SSC}$.

Histology. P4 and P23 mice were decapitated, and the brains were removed into Millonig's fixative (1.86 gm NaH${ }_{2} \mathrm{PO}_{4}, 0.42 \mathrm{gm} \mathrm{NaOH}, 4 \%$ formaldehyde in $100 \mathrm{ml}$ of water). The brains were embedded in paraffin, and $10 \mu \mathrm{m}$ sections were taken through the cerebellum. After they were mounted on glass slides, sections were stained with cresyl violet and coverslipped. The number of Purkinje cell bodies per $525 \mu \mathrm{m}$ wide field was compared between opt/opt and $+/+$ mice at P23. The sections were aligned horizontally to maximize cell number, and the Purkinje cell bodies were counted in 16 opt/opt and $14+/+$ fields.

Physiological analysis. P4 mice were decapitated, the brains were removed quickly into ice-cold Gey's Balanced Salt Solution (GBSS, Life Technologies, Gaithersburg, MD), and the cerebellum was dissected free. The cerebellum was placed on a block of $2 \%$ agar and sliced into sagittal $200 \mu \mathrm{m}$ sections using a brain slicer (Katz, 1987). The slices were cleaned of membranes and choroid plexus, and they were incubated for $30 \mathrm{~min}$ at $37^{\circ} \mathrm{C}$ in a bicarbonate-containing Ringer's solution containing (in $\mathrm{mM}$ ): $150 \mathrm{NaCl}, 2.5 \mathrm{KCl}, 3 \mathrm{CaCl}_{2}, 1 \mathrm{MgCl}_{2}, 10 \mathrm{HEPES}, 5 \mathrm{NaHCO}_{3}, 8$ glucose, $\mathrm{pH} 7.4$, with $10 \mu \mathrm{M}$ fura-2 AM and $10 \mu \mathrm{M}$ pluronic acid. Slices were then mounted on the stage of an inverted microscope (Nikon Diaphot, Melville, NY) and held in place with an overlying screen. The bath was perfused continuously with $95 \% \mathrm{O}_{2} / 5 \% \mathrm{CO}_{2}$-bubbled Ringer's solution. Neurons were imaged by alternate flashes of 340 and $380 \mathrm{~nm}$ light every $10 \mathrm{sec}$, except during peaks of $\mathrm{Ca}^{2+}$ changes when sampling occurred every $3 \mathrm{sec}$. Fura- 2 fluorescence emissions were collected at $510 \mathrm{~nm}$ by an intensifying CCD camera (Hamamatsu Photonic Systems, Bridgewater, $\mathrm{NJ}) ; 340 / 380$ ratios and images were analyzed and displayed by Image-1/ Fluor software (Universal Imaging, West Chester, PA). $\mathrm{Ca}^{2+}$-free $(\mathrm{Mg}$ replaced) Ringer's solution was applied 1-2 min before and during quisqualate (QA) to isolate the release of intracellular stores from sources of extracellular calcium. Between applications of $\mathrm{QA}, \mathrm{Ca}^{2+}$ containing Ringer's solution flowed for 2-3 min to replenish intracellular stores. Analysis of data and statistics was performed using Excel (Microsoft, Redmond, WA) and Cricket Graph (Computer Associates, San Diego, CA).

PCR assays for opt and $\mathrm{Mi}^{\mathrm{wh}}$ alleles. The number of $o p t$ and $M i^{\mathrm{wh}}$ alleles carried by the pups was determined by PCR analysis on tail-clip DNA. For the opt analysis, primer pair $1 \mathrm{~F} / 3 \mathrm{R}$ generated a product from animals carrying at least one opt $\mathrm{IP}_{3} \mathrm{R} 1$ allele, whereas primers from exon $\mathrm{C}$ (see $* 4$, Fig. 5A) amplified a band in DNA from mice carrying at least one wild-type $\mathrm{IP}_{3} \mathrm{R} 1$ allele. By using both primer pairs on the same DNAs, the $+/+,+/ o p t$, and opt/opt mice could be distinguished from one another.

The $M i^{\text {wh }}$ analysis used a nested PCR approach and the T to A point mutation at the $M i^{\text {wh }}$ locus (Steingrimsson et al., 1994). The A residue (bp 764) in $M i^{\text {wh }}$ is the first nucleotide of exon 7 (Tassabehji et al., 1994). Primers located $5^{\prime}$ of A(764) were designed from an unpublished intron sequence provided by E. Steingrimsson. The first PCR round used primer pair MiF1/MiR1, which perfectly matched the wild-type sequence and flanked the nucleotide residue altered in the $M i^{\mathrm{wh}}$ mice to generate a 120 bp product. Oligonucleotide MiF1 matches unpublished intronic sequence, and primer MiR1 corresponds to exon 7 sequence $5^{\prime}$ GATCATTTGACTTGGGGATC-3' (Hodgkinson et al., 1993). PCR was performed as described previously (Street et al., 1995), with an annealing temperature of $60^{\circ} \mathrm{C}$. This amplification product was diluted 1:100, and 2 
$\mu \mathrm{l}$ of this dilution served as the template for the second $25 \mu \mathrm{l} \mathrm{PCR}$ reaction, which was also performed with an annealing temperature of $60^{\circ} \mathrm{C}$. The second PCR round used primers MiF2/MiR2. Primer MiR2 matches exon 7 sequence 5'-TCATTTGACTTGGGGATCAGAGTACC-3' (Hodgkinson et al., 1993), whereas oligonucleotide MiF2 was designed based on unpublished intronic sequence immediately $5^{\prime}$ of residue $\mathrm{A}(764)$; however, two nts of the first six at the $3^{\prime}$ end of MiF2 did not match the wild-type sequence, but instead formed the first portion of an $X b a \mathrm{I}$ recognition site (TCTAG). Primers amplifying the $M i^{\mathrm{wh}}$ allele create an $\mathrm{XbaI}$ site (T/CTAGA), whereas primers using wild-type DNA as a template do not create the endonuclease recognition site (TCTAGT). By directly digesting $9 \mu \mathrm{l}$ of the second-round PCR amplification product with $X b a \mathrm{I}$ and running it on a 3\% Metaphor gel, the 26 bp size shift between $M i^{\mathrm{wh}}$ and wild-type DNA could be visualized, allowing $+/+,+/ M i^{\mathrm{wh}}$, and $M i^{\mathrm{wh}} / M i^{\mathrm{wh}}$ mice to be distinguished from one another.

\section{RESULTS}

\section{Genetic mapping}

To test whether a mutation in $\mathrm{IP}_{3} \mathrm{R} 1$ could be causally related to the opt mouse, we mapped the $\mathrm{IP}_{3} \mathrm{R} 1$ gene on an intersubspecific intercross segregating for opt (Fig. $1 A$ ). In this cross, $\mathrm{IP}_{3} \mathrm{R} 1$ was not separated from opt by a recombination event in 112 meioses (Fig. $1 B, C$ ), indicating that $\mathrm{IP}_{3} \mathrm{R} 1$ and opt are tightly linked genetically.

Genetic linkage between $\mathrm{IP}_{3} \mathrm{R} 1$ and opt was also suggested by analyzing mice from the heterozygous intercross $\left(M i^{\text {wh }},+/+\right.$, opt $\times M i^{\mathrm{wh}},+/+$,opt) used to propagate the opt mutation (Fig. $2 A$ ). The presence of the $M i^{\mathrm{wh}}$ mutation, which arose in a cross between DBA and C57BL, allows the opt colony to be maintained in part by coat color selection (Grobman and Charles, 1947). When a $3^{\prime}$ untranslated $\mathrm{IP}_{3} \mathrm{R} 1$ DNA fragment was hybridized to Southern blots containing $M i^{\text {wh }}$ homozygote, $M i^{\text {wh }} / o p t$ heterozygote $\left(M i^{\mathrm{wh}},+/+, o p t\right)$, and opt homozygote DNAs, the probe detected an RFLV between $M i^{\text {wh }}$ and opt homozygotes (Fig. 2B). Given that the opt colony has been maintained in our laboratory by brother-sister intercrossing for 50 generations (N50), unselected loci would have been driven to homozygosity unless the gene was tightly linked to either of the two selected mutations, $M i^{\mathrm{wh}}$ or opt. The probability of heterozygosity at an unselected locus such as $\mathrm{IP}_{3} \mathrm{R} 1$ in this cross at N50 would be $2.2 \times 10^{-5}$. Therefore, our finding of heterozygosity at the $\mathrm{IP}_{3} \mathrm{R} 1$ locus in all N50 opt-carrying mice that were analyzed $(n=3)$ supports the previous finding that this gene and opt are tightly linked genetically.

\section{Expression of $\mathrm{IP}_{3} \mathrm{R} 1$ in opt}

Expression of $\mathrm{IP}_{3} \mathrm{R} 1 \mathrm{mRNA}$ in the brains of opt mice was examined by Northern blot analysis. $M i^{\text {wh }}$ homozygote mice displayed a transcript of $\sim 10 \mathrm{~kb}$ (Fig. $3 A$, lane 2), whereas the opt homozygotes contained a slightly smaller transcript (lane 5), with $M i^{\text {wh }} / o p t$ heterozygotes demonstrating both mRNA species (lanes 3, 4). Although size differences were observed, the intensity of each $\mathrm{IP}_{3} \mathrm{R} 1$ transcript in the $M i^{\mathrm{wh}} / o p t$ heterozygotes was similar, as was the band intensity between age-matched $M i^{\text {wh }}$ and opt homozygotes, suggesting that $\mathrm{IP}_{3} \mathrm{R} 1 \mathrm{mRNA}$ levels are not reduced dramatically by the opt mutation.

To further characterize the altered $\mathrm{IP}_{3} \mathrm{R} 1$ transcript, RT-PCR was performed on whole-brain RNA from a $M i^{\text {wh }}$ homozygote, a $M i^{\mathrm{wh}} / o p t$ heterozygote, and an opt homozygote pup, with overlapping PCR primer pairs spanning the 8247 bp $\mathrm{IP}_{3} \mathrm{R} 1 \mathrm{ORF}$ and immediate $5^{\prime}$ and $3^{\prime}$ flanking regions. Aberrant opt RT-PCR products were detected with only one primer pair $(11 \mathrm{~F} / 12 \mathrm{R})$ (Nakagawa et al., 1991) positioned within the modulatory and transducing domain (Furuichi and Mikoshiba, 1995). Primers
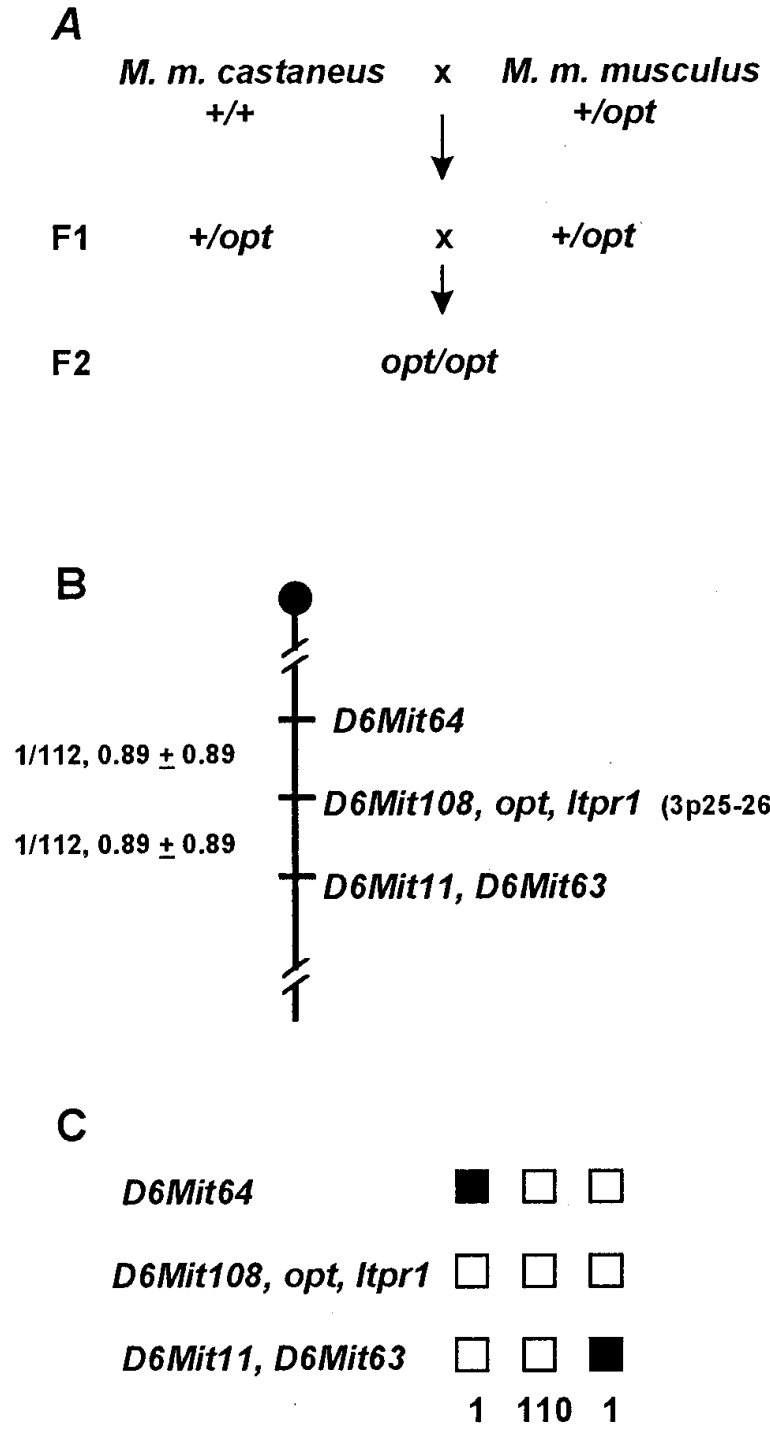

Figure 1. Location of the $\mathrm{IP}_{3} \mathrm{R} 1$ gene relative to the opt locus. $A$, An intersubspecific intercross was established segregating for opt. B, Four microsatellites and a novel PCR marker derived from the $\mathrm{IP}_{3} \mathrm{R} 1$ gene were mapped in the 56 progeny from the intersubspecific intercross. The number of recombination events observed among the 112 intercross chromosomes analyzed, and genetic distances in centimorgans $( \pm \mathrm{SE})$ separating adjacent loci, are represented by the numbers to the left of the chromosome. The human homolog of the mouse $\mathrm{IP}_{3} \mathrm{R} 1$ gene maps to the short arm of chromosome 3 , as noted in parentheses to the right of the mouse gene (Yamada et al., 1994). $C$, One hundred twelve chromosomes from the 56 intersubspecific intercross progeny were scored for parental C57BL/Ks-opt/opt (open boxes) and CAST/Ei-+/+ DNAs (filled boxes) at five loci. The number of chromosomes for each haplotype is shown below the columns.

11F/12R amplified a 648 bp product from $M i^{\text {wh }}$ homozygote RNA (Fig. 3B, lane 2), which was slightly smaller because of alternative splicing in the SII region (Nakagawa et al., 1991) than the $699 \mathrm{bp}$ area spanned by these oligonucleotides in the published cerebellar $\mathrm{IP}_{3} \mathrm{R} 1$ cDNA nucleotide sequence (Furuichi et al., 1989a). Although $11 \mathrm{~F} / 12 \mathrm{R}$ generated one product from $M i^{\text {wh }}$ homozygote RNA, the same primer pair amplified at least three smaller products in opt homozygotes (lane 5), with $M i^{\text {wh }} / o p t$ heterozygotes seeming to generate all of the products (lanes 3,4). Cloning and analysis of these RT-PCR products indicated that at least four 

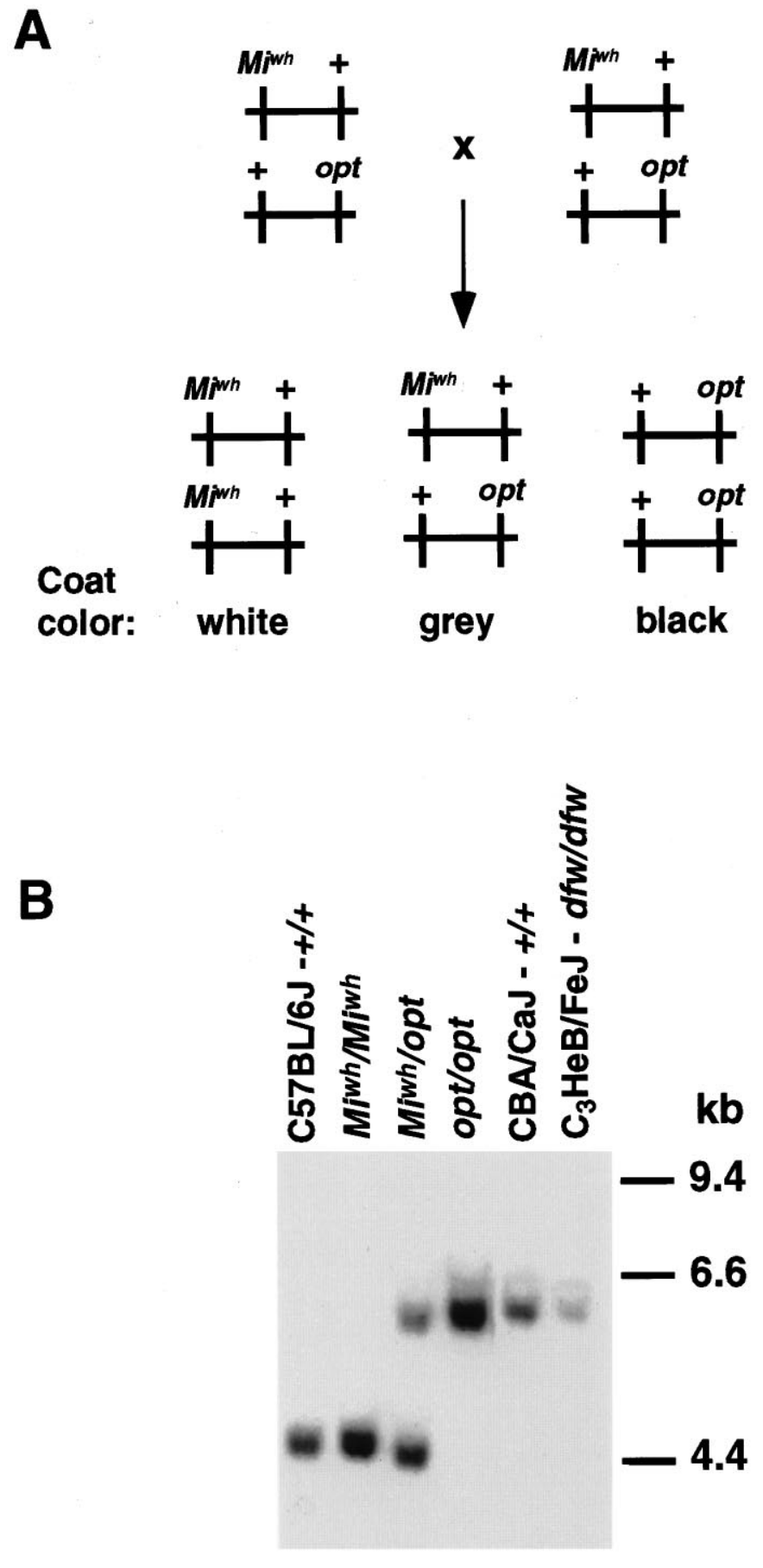

Figure 2. Heterozygosity at the $\mathrm{IP}_{3} \mathrm{R} 1$ locus. $A$, Maintenance of the opt colony. $B$, Southern blot hybridization analysis demonstrates an interstrain RFLV with a probe derived from the $3^{\prime}$ untranslated region of the $\mathrm{IP}_{3} \mathrm{R} 1$ gene.

alternatively spliced RNA species were present in the brains of $o p t$ homozygotes, with all transcripts lacking the 5194-5517 nucleotide (nt) area encoding amino acids 1732-1839 (Fig. 3C). Several regulatory sites are contained within this area: a cGMPdependent (GKA) (Komalavilas and Lincoln, 1994) and cAMPdependent protein kinase (PKA) (Ferris et al., 1991) phosphorylation site at amino acid residue 1755, and at least one potential ATP binding domain at 1773-1778 (Fig. 3C). Although the opt transcript type 2 lacks only nucleotide residues $5194-5517$, the opt type 1, 3, and 4 transcripts have additional domains deleted $5^{\prime}$ of this area (Fig. $3 C$ ). The splice junctions to remove these domains are also used in pre-mRNA from wild-type mice, as shown previously (Nakagawa et al., 1991), and are referred to as the SII region (nt residues 1692-1731) containing segment A (16921714), B (1715), and C (1716-1731). The exon skipping displayed by all four opt transcript subtypes does not result in translational frameshifts or premature stop codons, leaving the transcript unaltered $3^{\prime}$ of exon D.

To determine whether the altered transcripts seen in opt are translated, Western blot analysis was performed on cerebellar microsomes with two polyclonal antibodies made against $\mathrm{IP}_{3} \mathrm{R} 1$ peptide antigens specific to $\mathrm{IP}_{3} \mathrm{R} 1$ (Lin, 1995) (Fig. 4). The first antibody, SP-3A, was raised against amino acid residues 24852501 , which are located $3^{\prime}$ of the area deleted in the $\mathrm{IP}_{3} \mathrm{R} 1$ mRNA from opt. This antibody recognized a protein migrating at $\sim 255$ $\mathrm{kDa}$ in the 3-month-old C57BL/6- $/++, \mathrm{P} 12 M i^{\mathrm{wh}}$ homozygote, and P12 $\mathrm{Mi}^{\mathrm{wh}} /$ opt heterozygote lanes, and a protein migrating slightly faster at $245 \mathrm{kDa}$ in the lanes from two opt homozygotes (P12 and P19) (Fig. 4). Staining with SP-3A confirms that the $\mathrm{ORF}$ of the $\mathrm{IP}_{3} \mathrm{R} 1$ protein is maintained in opt homozygotes, although the level of expression was markedly reduced. P12 and P19 opt homozygotes show similarly decreased expression levels of cerebellar $\mathrm{IP}_{3} \mathrm{R} 1$ protein. Quantification of $\mathrm{IP}_{3} \mathrm{R} 1$ protein levels using SP-3A and iodinated Protein A indicated that the P12 opt homozygote and $\mathrm{Mi}^{\mathrm{wh}} / \mathrm{opt}$ heterozygote expression was $10 \%$ and $67 \%$, respectively, of their $M i^{\text {wh }}$ homozygote littermate (data not shown).

The second antibody, SP-2A, recognizes residues 1745-1760 (Fig. $3 C$ ), which fall within the region deleted from all of the opt transcripts. This antibody detected a $255 \mathrm{kDa}$ band in the C57BL/6-+/+, $M i^{\text {wh }}$ homozygote, and $M i^{\text {wh }} /$ opt heterozygote lanes, but not in the two opt homozygote lanes. These protein and RNA blots, combined with the RT-PCR and sequence data, indicate that opt mice contain aberrantly spliced $\mathrm{IP}_{3} \mathrm{R} 1$ mRNA transcripts, which lead to the production of $\mathrm{IP}_{3} \mathrm{R} 1$ protein missing several potential regulatory sites, with the altered protein being present at markedly reduced levels.

\section{Genomic structure of $\mathrm{IP}_{3} \mathrm{R} 1$ in opt}

To investigate the underlying cause of the aberrant splicing of the opt $\mathrm{IP}_{3} \mathrm{R} 1 \mathrm{mRNA}$, the genomic structure of the gene from exon A to exon D was compared in wild-type and opt homozygote DNA (Fig. 5A). The comparison indicated that opt homozygotes contain a $>10 \mathrm{~kb}$ genomic DNA deletion that begins 298 bp $3^{\prime}$ of exon A (Fig. 5B) and ends in intron 3 (size unknown) at a site $>1 \mathrm{~kb} 3^{\prime}$ of exon $\mathrm{C}$ and $>7 \mathrm{~kb} 5^{\prime}$ of exon $\mathrm{D}$ (Fig. $5 A$ ). Hybridization of the wild-type $3.4 \mathrm{~kb} N s i$ I genomic fragment, spanning exon B and part of exon C, to Southern blots containing NsiI-digested DNAs from C57BL/6J-+/+, $\mathrm{CBA} / \mathrm{Ca}-+/+, M i^{\mathrm{wh}}$ homozygote, $M i^{\mathrm{wh}} / o p t$ heterozygote, and opt homozygote DNA, confirmed that a large region was deleted in the opt genome. The probe hybridized to an appropriately sized fragment in all of the DNAs except for the opt homozygote, where no hybridization signal was detected (Fig. $5 C$ ). Five PCR primer pairs were designed from the wild-type nucleotide sequence suspected to be deleted in opt (Fig. 5A). All of the primers amplified the expected size product from C57BL $/ 6 \mathrm{~J}-+/+$ and $M i^{\text {wh }}$ homozygote DNA, but failed to generate a product when opt homozygote DNA was used as a template. PCR primer pairs were also generated from the nucleotide sequence of a $3.0 \mathrm{~kb} X b a \mathrm{I}$ opt genomic fragment 


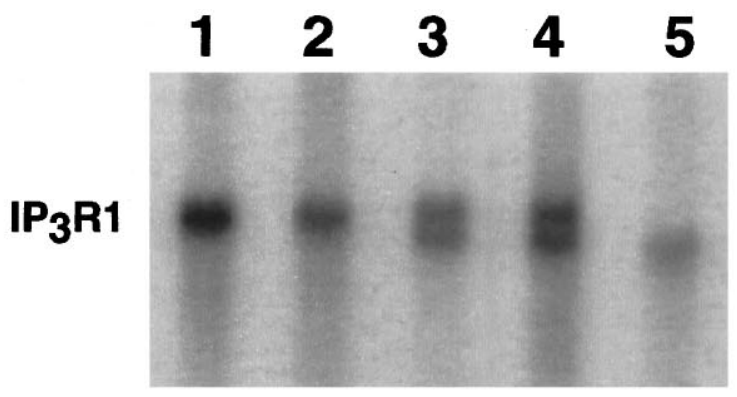

B
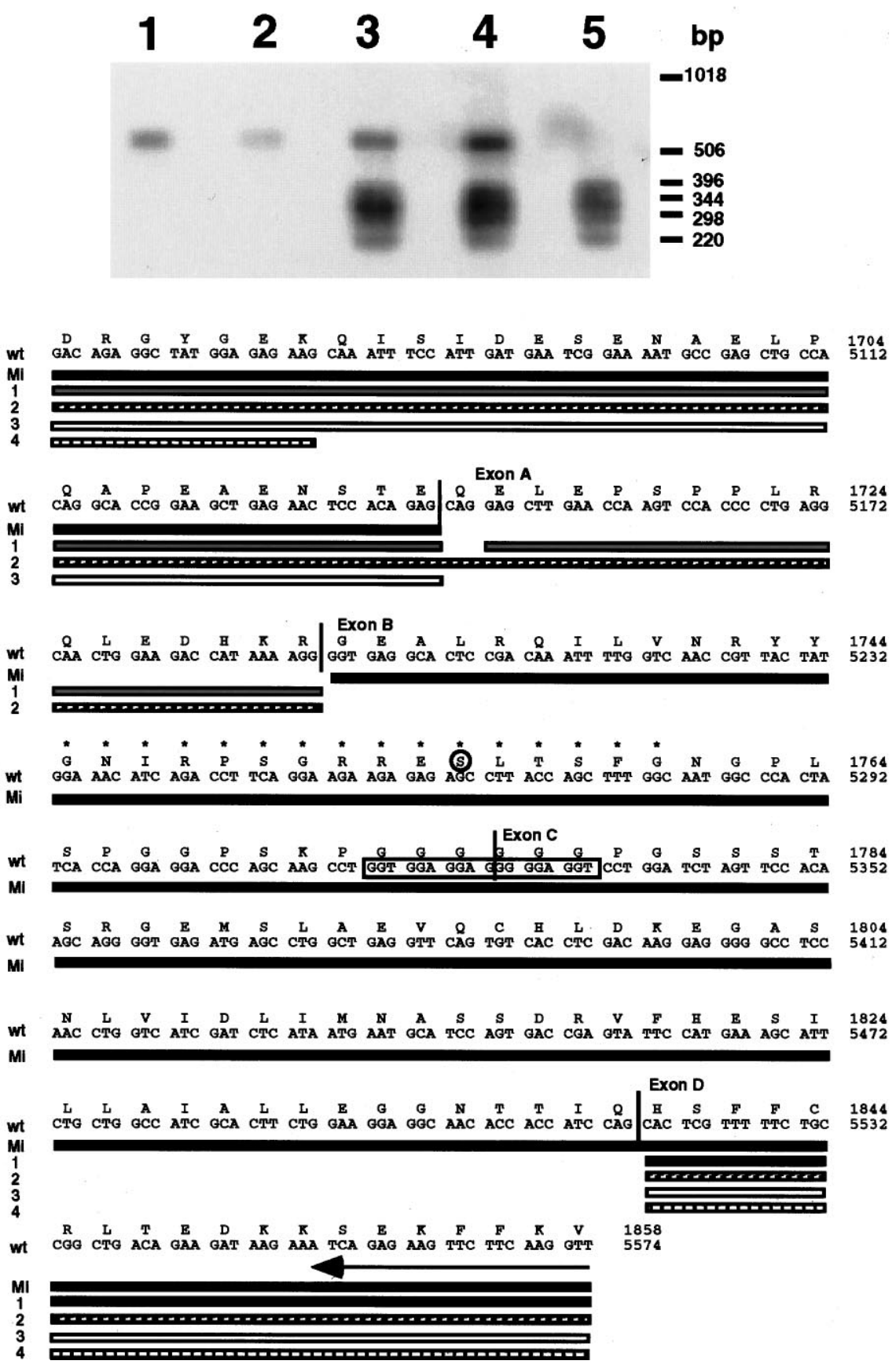

Figure 3. Expression of $\mathrm{IP}_{3} \mathrm{R} 1 \mathrm{mRNA}$ in opt brain. $A, \mathrm{IP}_{3} \mathrm{R} 1$ transcript size is reduced in opt homozygote mice. From left to right, lanes $1-5$ represent total brain RNA from a P13 C57BL/6J-+/+, P13 $M i^{\text {wh }}$ homozygote, P11 $M i^{\text {wh }} / o p t$ heterozygote, adult $M i^{\text {wh }} / o p t$ heterozygote, and P13 opt homozygote mouse. An identically loaded Northern gel was electrophoresed for a shorter duration in parallel to the one shown here to retain smaller size transcripts. This blot was probed with EF $1 \alpha$ (Xiang and Werner, 1989) to control for lane loading. $B$, RT-PCR analysis of $\mathrm{IP}_{3} \mathrm{R} 1$ mRNA with primers $11 \mathrm{~F} / 12 \mathrm{R}$; lanes $1-5$ as above. $C$, Primary structure of altered $\mathrm{IP}_{3} \mathrm{R} 1$ mRNA species in opt homozygotes generated with primers $11 \mathrm{~F} / 12 \mathrm{R}$. Primer $12 \mathrm{R}$ is underlined by an arrow. Primer $11 \mathrm{~F}$ located at $\mathrm{nt}$ $4875-4897$ is not shown. The first and second line contain the amino acid (Furuichi et al. 1989b) and nucleotide sequence (Furuichi et al., 1989a) of the cerebellar $\mathrm{IP}_{3} \mathrm{R} 1$ cDNA, respectively. The nucleotide sequence is numbered from the $5^{\prime}$ to $3^{\prime}$ direction where +1 was assigned to the first base of the predicted initiation codon. Line three displays a nucleotide sequence of the RT-PCR product from $M i^{\mathrm{wh}}$ homozygote RNA, and lines 4-7 display the four different products from opt homozygote RNA, labeled 1-4. Exon borders determined by genomic sequence analysis are indicated by vertical lines. A GKA and PKA phosphorylation site is circled, and a putative ATP-binding domain is boxed. Asterisks denote amino acids used to generate antibody SP-2A. containing the fusion point (Fig. 5B). Primers 1F/3R, which span the fusion point, amplified a product from opt but not wild-type genomic DNA under standard PCR amplification conditions (data not shown). Primer pairs positioned immedi- ately $5^{\prime}(1 \mathrm{~F} / 2 \mathrm{R})$ or $3^{\prime}(4 \mathrm{~F} / 5 \mathrm{R})$ of the fusion point amplified the expected size product in both $\mathrm{C} 57 \mathrm{BL} / 6 \mathrm{~J}-+/+$ and opt homozygote genomic liver DNA. PCR analysis with primers $4 \mathrm{~F} / 5 \mathrm{R}$ indicate that the opt sequence $3^{\prime}$ of the fusion point is from 


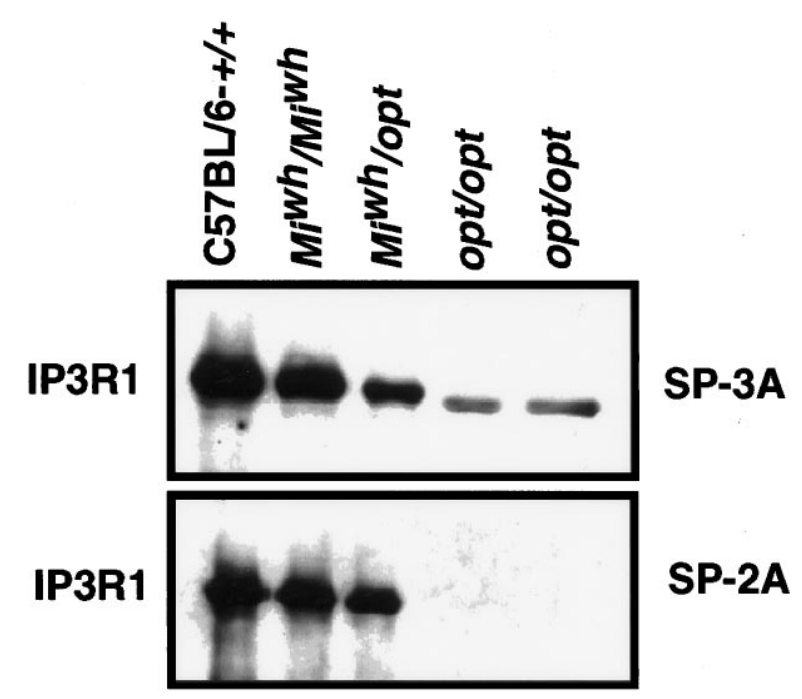

Figure 4. Expression of $\mathrm{IP}_{3} \mathrm{R} 1$ protein in opt cerebellum. Western blot analysis of cerebellar microsomal membrane fractions from a 3-month-old C57BL/6-+/+, P12 Mi ${ }^{\mathrm{wh}}$ homozygote, P12 Mi ${ }^{\mathrm{wh}} /$ opt heterozygote, P12 opt homozygote, and P19 opt homozygote with antibodies SP-3A and SP-2A (Lin, 1995). P12 pups are littermates.

intron 3 , because the expected size product is generated from a B6/CBA-+/+ wild-type phage genomic insert lacking exon $\mathrm{C}$ but containing intronic DNA from between exons $\mathrm{C}$ and $\mathrm{D}$, and exon D. This genomic DNA analysis data indicates that the aberrant splicing of the $\mathrm{IP}_{3} \mathrm{R} 1$ mRNA in opt homozygotes is caused by a large genomic deletion that removes the majority of intron 1 , all of exon $\mathrm{B}$, intron 2 , and exon $\mathrm{C}$, and a portion of intron 3 , and leaves exons $\mathrm{A}$ and $\mathrm{D}$ intact.

Comparison of the wild-type genomic nucleotide sequence with that of the published cerebellar $\mathrm{IP}_{3} \mathrm{R} 1$ cDNA (Furuichi et al., 1989a) allows the exon/intron boundaries (Padgett et al., 1986) to be determined for this section of the $\mathrm{IP}_{3} \mathrm{R} 1$ gene, as noted in Figure $3 C$. This analysis indicates that exons $\mathrm{A}$ and $\mathrm{D}$ can be fused in opt homozygote mRNA without creating a premature stop codon or translational frameshift, because introns 1 and 3 are both phase 0 introns (Sharp, 1981) interrupting the reading frame between codons (Fig. 5D). Therefore the original ORF is shortened because it is missing exons $\mathrm{B}$ and $\mathrm{C}$ but otherwise is maintained.

\section{Cerebellum morphology}

The cerebella of control and opt homozygote mice compared at P4 and P23 show no apparent differences at the light microscope level (Fig. 6). At P4, the mature architecture of the cerebellum is not yet seen, and the Purkinje neuron layer is only a relatively narrow band between the granular and molecular layers (Fig. $6 A-D)$. The gross appearance of the $\mathrm{P} 4$ tissue is similar between control and opt pups. At P23, a mature appearance is seen in both control and opt cerebella (Fig. 6E-H). The normal, ordered arrangement of the Purkinje cell layer to molecular and granular layers is observed (Fig. 6E,D). At a higher magnification (Fig. $6 G, H)$, the cell bodies of Purkinje neurons appear similar in size and density when compared between genotypes. The average number of Purkinje cell bodies/field in a P23 mouse was $19.1 \pm$ 0.6 for $o p t$ homozygotes and $19.2 \pm 0.9$ for control pups. These anatomical findings suggest that the 10 -fold reduction in cerebellar $\mathrm{IP}_{3} \mathrm{R} 1$ protein expression seen in the P12 and P19 opt homozygotes is not attributable to Purkinje cell death. The architecture of the cerebella from P4 and P23 Mi ${ }^{\text {wh }}$ homozygote pups and from $\mathrm{P} 4 M i^{\mathrm{wh}} / o p t$ heterozygotes was indistinguishable from that of the cerebella shown here.

\section{Physiological analysis}

As a first step toward investigating the physiological consequences of having exons $\mathrm{B}$ and $\mathrm{C}$ deleted from the $\mathrm{IP}_{3} \mathrm{R} 1$ protein, a cerebellar slice preparation was used to ask whether any biological differences in release from $\mathrm{IP}_{3}$-sensitive calcium stores could be detected between P4 opt mutants and wild-type littermates when the inositol-phospholipid pathway was activated by an extracellular signal. A slice preparation was chosen to maintain cellular components that might be critical in modulating the response. Cerebellar slices were used because cerebellar Purkinje cells show enriched levels of $\mathrm{IP}_{3} \mathrm{R} 1$ (Furuichi et al., 1993), with $\mathrm{IP}_{3} \mathrm{R} 1$ expression accounting for $\sim 94 \%$ of the $\mathrm{IP}_{3} \mathrm{R}$ mRNA in the cerebellum. The remaining $6 \%$ is constituted by expression of mRNA for $\mathrm{IP}_{3} \mathrm{R} 2$ and $\mathrm{IP}_{3} \mathrm{R} 3$, and putative isoforms $\mathrm{IP}_{3} \mathrm{R} 4$ and $\mathrm{IP}_{3} \mathrm{R} 5$ (De Smedt et al., 1994). Cerebellar slices were taken from P4 pups for several reasons. First, the somata of the P4 Purkinje neurons is $\sim 15 \mu \mathrm{m}$ in diameter and is ordered in a characteristic array (Fig. 6), allowing individual Purkinje cell bodies to be resolved easily and distinguished clearly from other non-Purkinje cells within the slice preparation at the light microscope level. Second, $\mathrm{IP}_{3} \mathrm{R} 1$ and metabotropic glutamate receptor 1 (mGluR1) are both expressed on the somata of mouse Purkinje neurons by P3 (Ryo et al., 1993), with mGluR5 being expressed in the Purkinje cell layer at the same developmental time (Bettler et al., 1990). Within the mGluR family, mGluR1 and mGluR5 comprise Group I, which is characterized by linkage to the phospholipase $\mathrm{C} / \mathrm{IP}_{3}$ cascade pathway, and by the following potency rank order for agonists: QA $>$ L-glutamate $>$ ibotenate $>\left(2 \mathrm{~S}, 1^{\prime} \mathrm{S}, 2^{\prime} \mathrm{S}\right)-2-$ (carboxycyclopropyl)glycine $>(1 S, 3 R$-ACPD) (Pin and Duvoisin, 1995). By the equivalent of P4, the percentage of Purkinje neurons exhibiting metabotrophic responses to QA application is maximal, with the response being localized primarily to the soma (Yuzaki and Mikoshiba, 1992). We therefore chose to use QA to activate the inositol-phospholipid pathway in the P4 cerebellar slice preparations. Although QA is most effective at activating the Group I mGluR, it is also active on the ionotropic AMPA-type GluRs (Pin and Duvoisin, 1995); therefore, to ensure that QA was mediating only $\mathrm{Ca}^{2+}$ release from intracellular stores, the compound was always applied in $\mathrm{Ca}^{2+}$-free extracellular solution.

P4 cerebellar tissue slices were loaded with the membranepermeate $\mathrm{Ca}^{2+}$ indicator dye fura-2 AM and then challenged with QA in $\mathrm{Ca}^{2+}$-free external solution (Llano et al., 1991; Yuzaki and Mikoshiba, 1992). A cerebellar field was visualized at $400 \times$ magnification by a light microscope and displayed on a video screen. A typical cerebellar field at this magnification contained an array of 4-12 Purkinje neuron somata. The image analysis software allowed individual Purkinje cell bodies to be selected for imaging by outlining the somata on the video screen. The slice was then alternately exposed to 340 and $380 \mathrm{~nm}$ wavelength light, allowing quantitation of calcium release from intracellular stores for the selected Purkinje somata. So although the entire slice was loaded with fura-2 AM, we were measuring responses only from the cell bodies of selected Purkinje neurons. Only slices in which all Purkinje neurons in the field appeared healthy based on their initial calcium content and their $\mathrm{KCl}$ response at the end of the experiment were considered in the analysis. In several experiments, non-Purkinje cells were also selected for imaging, and in no case did these cells respond to agonist application. 


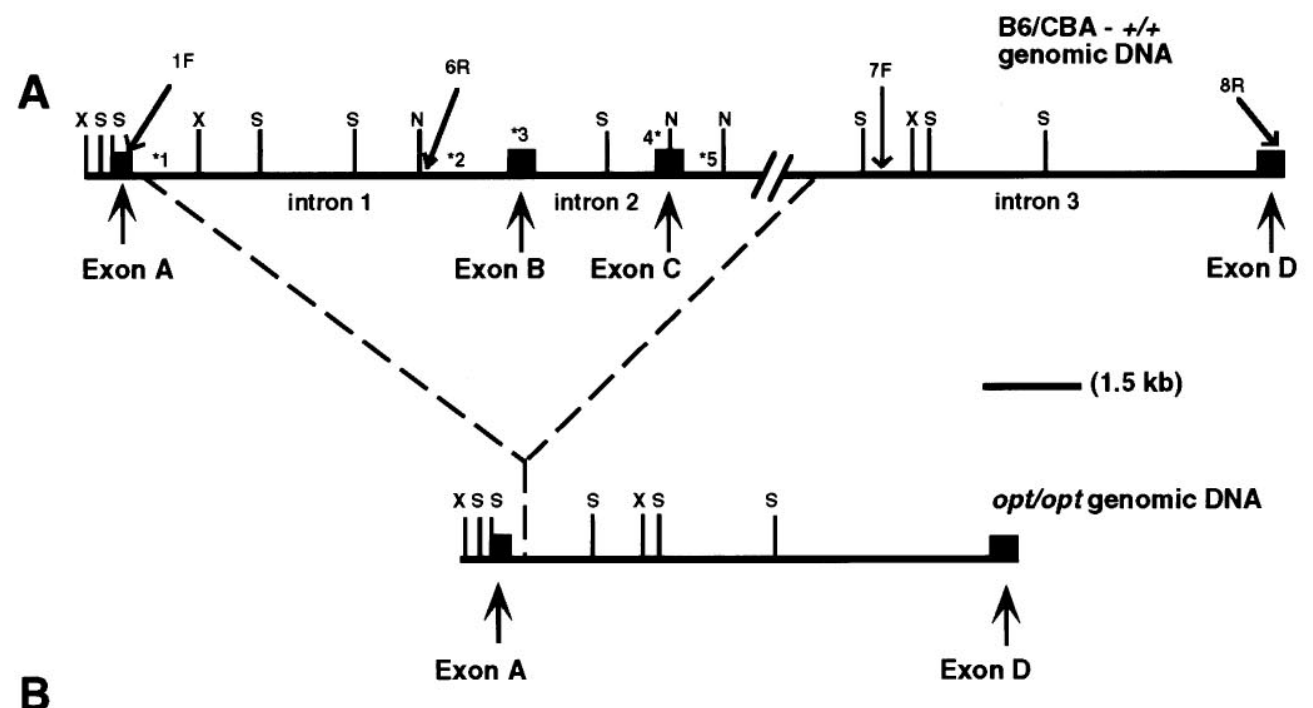

Exon A
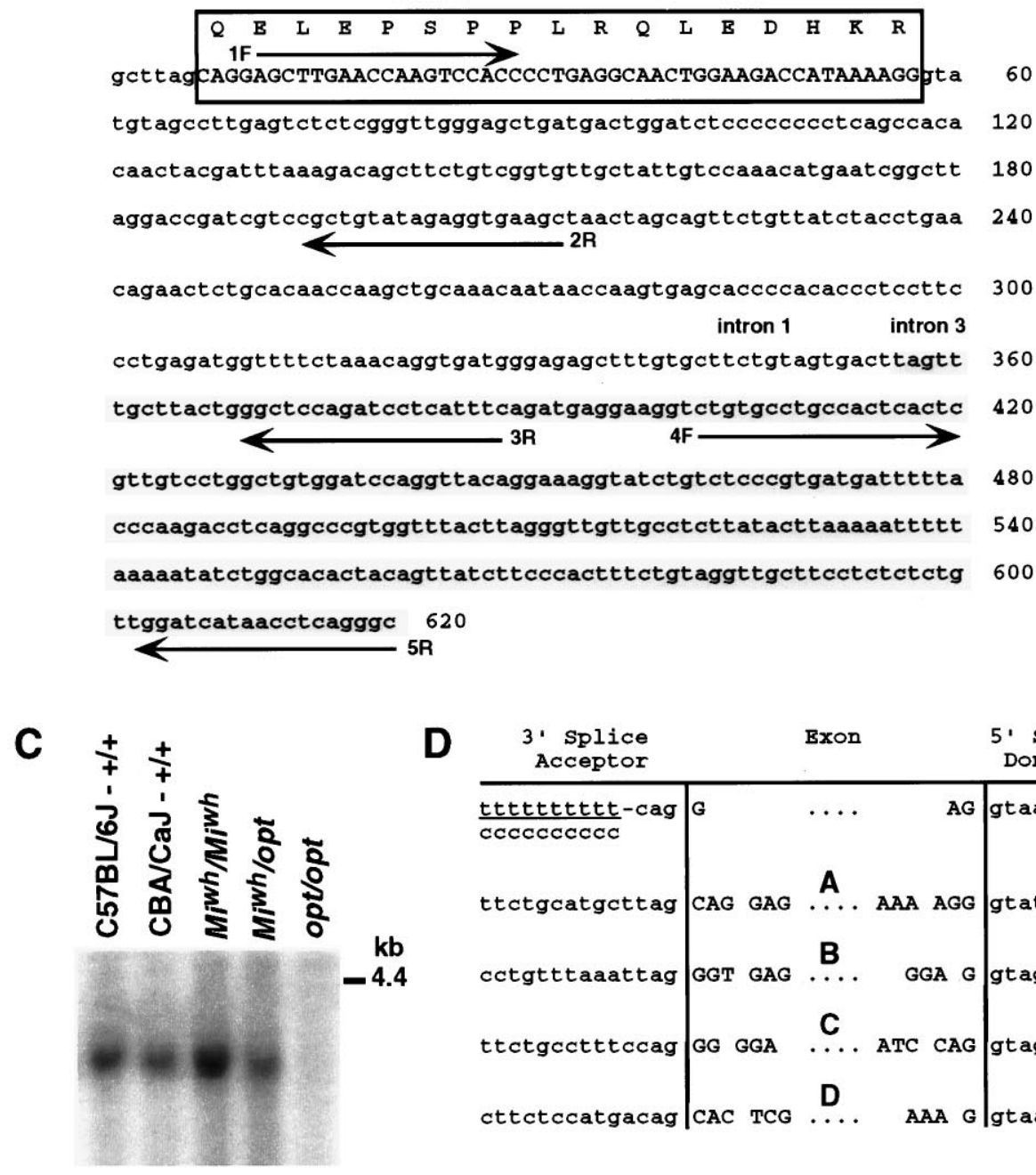

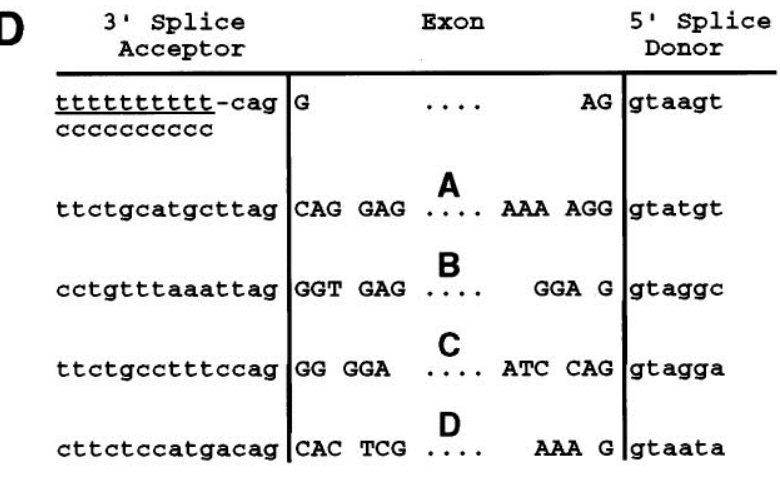

Figure 5. Genomic analysis of opt locus. $A$, Comparison of wild-type and mutant genomic structure reveals deletion in opt DNA. Wild-type composite diagram (top line) was constructed using restriction mapping, Southern blot hybridization, sequencing, and PCR-based approaches in $\mathrm{B} 6 / \mathrm{CBA}-+/+$ genomic DNA derived from a $\lambda$ phage library. Exons are depicted as filled boxes and intervening introns as a solid line. Bases of the mouse cerebellar $\mathrm{IP}_{3} \mathrm{R} 1 \mathrm{cDNA}$ corresponding to the beginning and end of each exon are as follows: A (50745142), B (5143-5193), C (5194-5517), and $\mathrm{D}(5518-5698) .1 F, 6 R, 7 F$, and $8 R$ are expand PCR primers. Asterisks indicate the location of five PCR primer pairs used to confirm the extent of the genomic deletion in opt. The lower line depicts an opt homozygote genomic DNA map based on restriction analysis of subcloned fragments derived from a custom-made opt homozygote $\lambda$ phage library. Restriction endonuclease sites are designated as follows: $S, \operatorname{SacI} ; X$, $X b a \mathrm{I}$; and $N, N s i \mathrm{I}$. Not all restriction sites are shown. $B$, The deletion in $o p t$ DNA fuses introns 1 and 3. Exon $A$ is boxed, intron 3 sequence is shaded, and PCR primers are designated by arrows. $C$, Southern blot hybridization analysis demonstrates that a $3.4 \mathrm{~kb} N$ siI fragment is deleted in opt genomic DNA. $D$, The intron/exon slice boundaries for exons $A, B, C$, and $D$ are compared with a consensus splice sequence.
The traces in Figure $7 A$ (top) show $\mathrm{Ca}^{2+}$ responses in several Purkinje neurons from a wild-type $(+/+$; left $)$ and an $o p t$ homozygote cerebellar brain slice (right) during three consecutive applications of QA. Each colored trace depicts the response from one individual Purkinje neuron. The ensemble of colored traces represents all of the Purkinje neurons monitored simultaneously in a single experiment. The color images in Figure $7 A$ (bottom) are from two Purkinje neuron somata within these same two slices [+/+ (left) and opt homozygote (right)] and show 340/380 nm intensity ratios in the somata at three time points $(A, B, C)$ during the experiment. The first QA application $(Q A 1)$ is able to generate a substantial calcium response from both $+/+$ and opt ho- 


\section{P4}
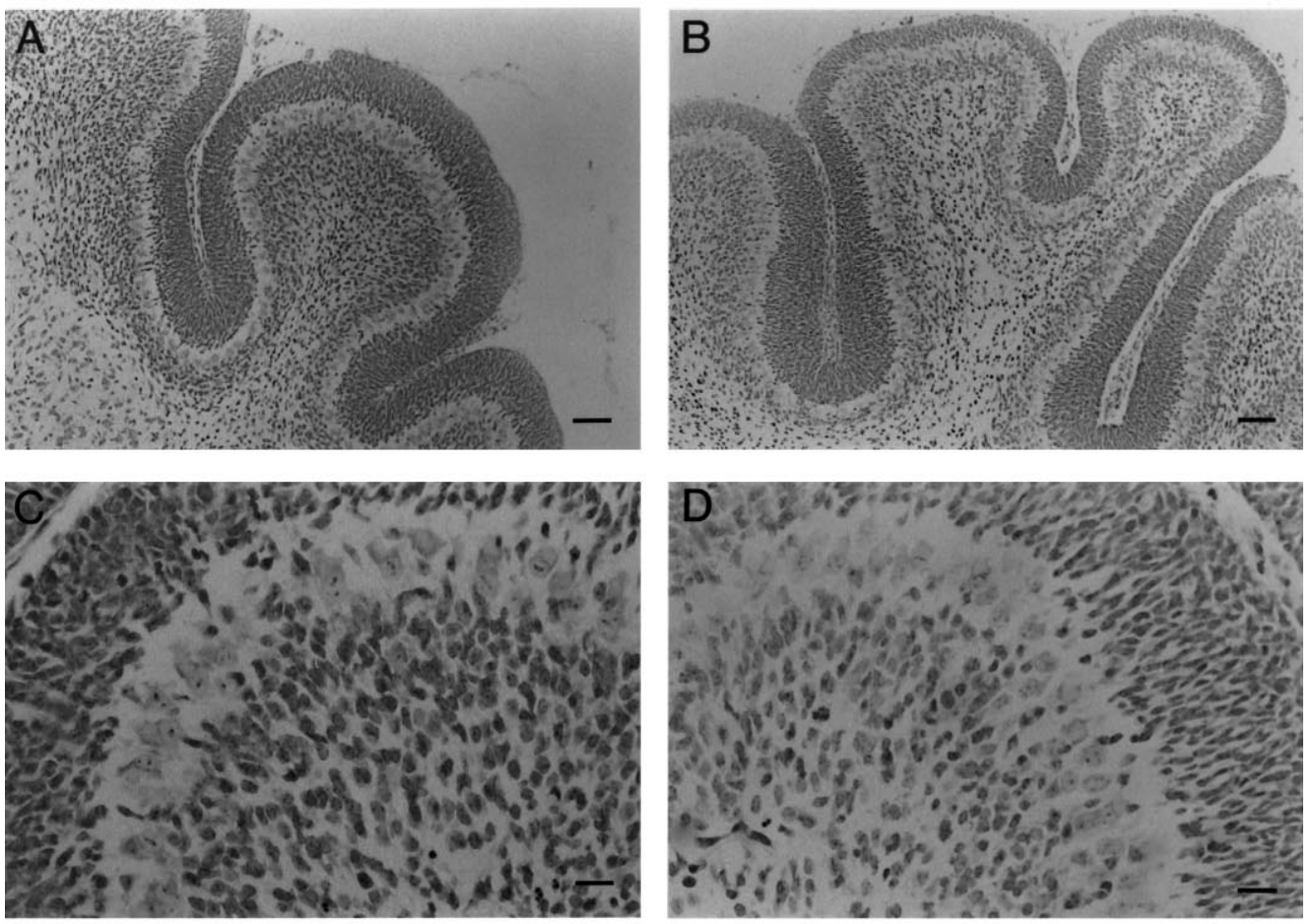

\section{P23}
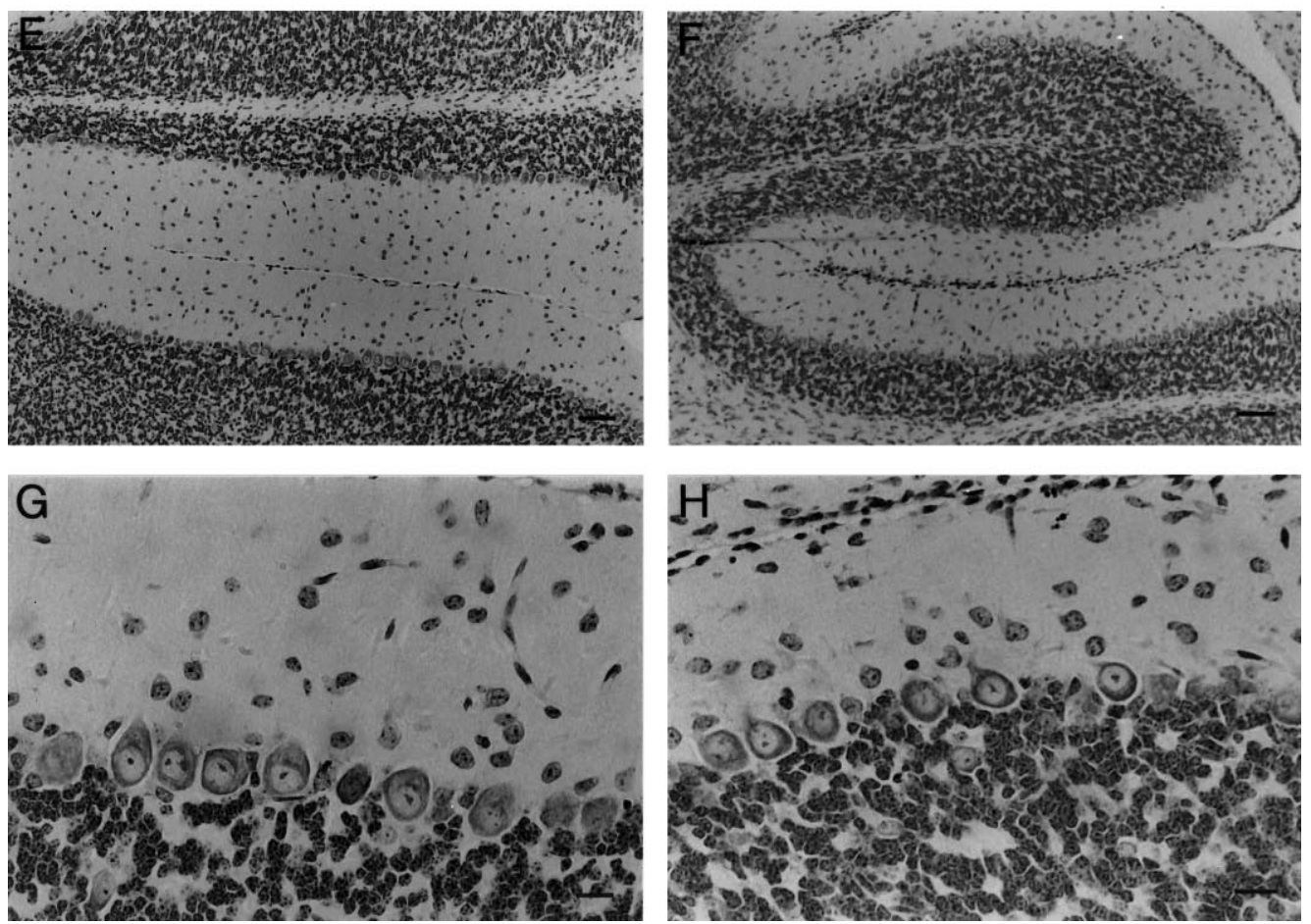

Figure 6. Paraffin sections of cerebellum stained with cresyl violet. P4 pups are shown in $A-D, \mathrm{P} 23$ mice in $E-H$. Control C57BL/6J-+/+ mice are shown on the left, opt homozygote mice on the right. Scale bars: $A, B, E, F, 200 \mu \mathrm{M} ; C, D, G, H, 50 \mu \mathrm{M}$.

mozygote Purkinje neurons. After allowing for refilling of internal calcium stores by exposure to 2 min of $\mathrm{Ca}^{2+}$-containing Ringer's solution between challenges, repeated application of the same QA dose $(Q A 2, Q A 3)$ continued to elicit large responses in opt ho- mozygotes, whereas $+/+$ mice responded poorly to both the second and third applications of QA (Fig. 7A). After QA application, cells from opt homozygote slices returned to baseline $\mathrm{Ca}^{2+}$ levels, whereas a subset of $+/+$ and heterozygote $\mathrm{P} 4$ cells in some 

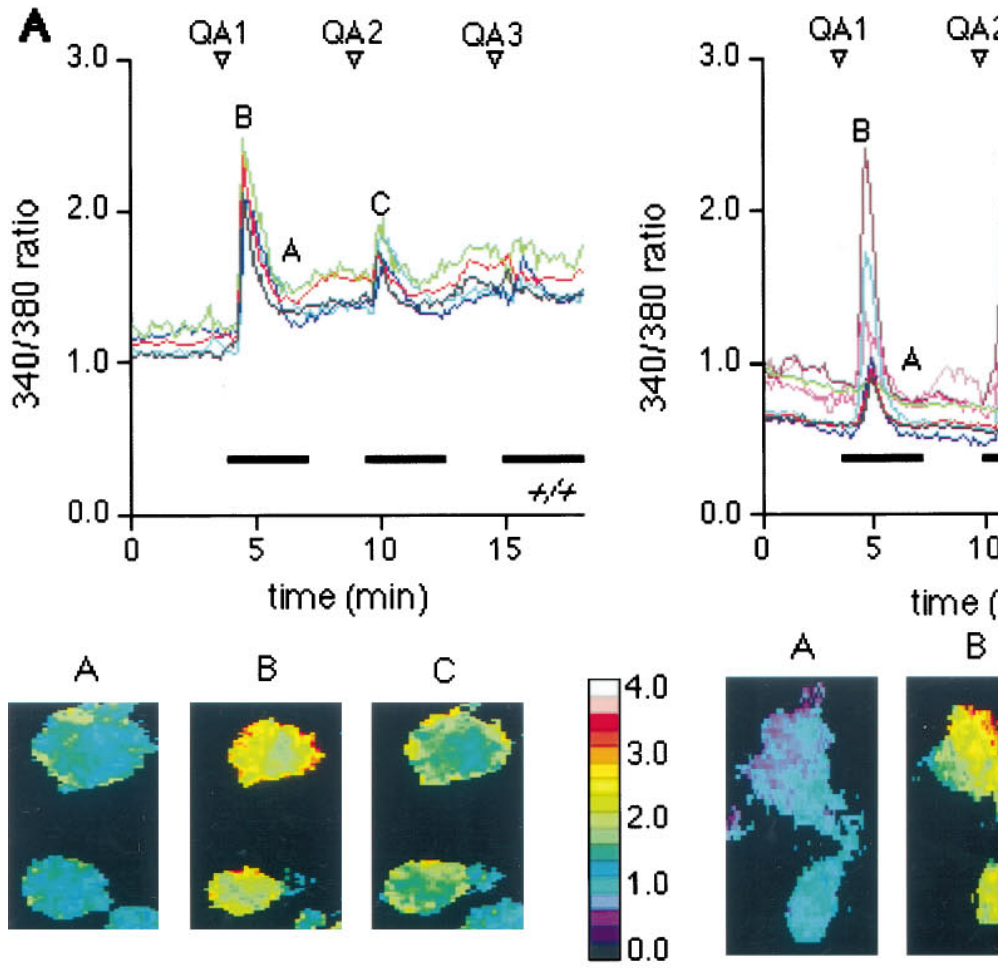

$\underset{\nabla}{\mathrm{QA} 3}$

B

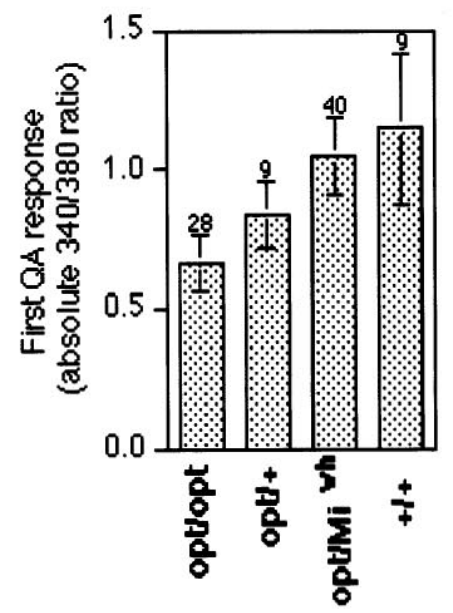

\section{C}

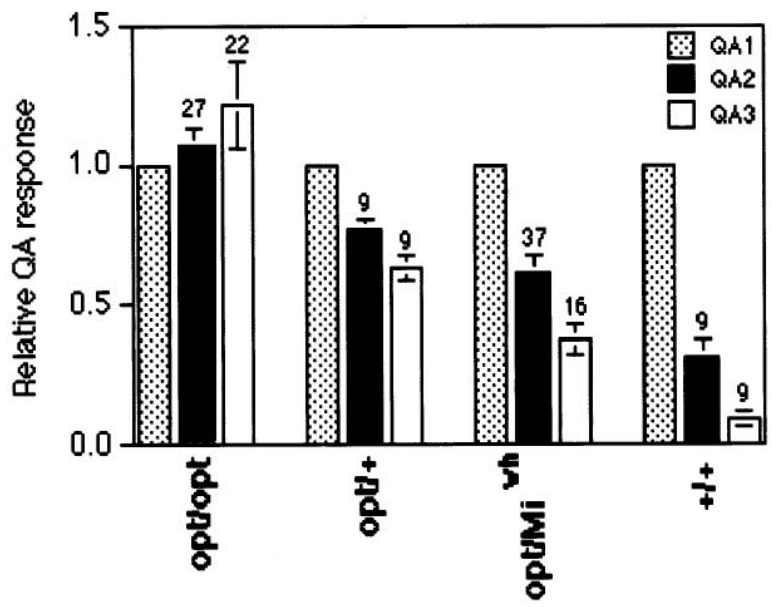

Figure 7. Physiological analysis of opt mutation. $A$, Examples of experiments in $+/+$ (left) and opt/opt (right) cerebellar slices showing 340/380 ratios of each of several Purkinje neurons in the field under control conditions and in response to repeated 30 sec $100 \mu \mathrm{M}$ QA application in $\mathrm{Ca}^{2+}$-free Ringer's solution. Each colored trace represents the response from one individual Purkinje neuron. Images were taken at points indicated in traces above where $A$ is the control, and $B$ and $C$ are the responses to the first and second QA application, respectively. Blue bars show periods of $\mathrm{Ca}^{2+}$-free Ringer's solution flow. Higher 340/380 ratios refer to higher $\mathrm{Ca}^{2+}$ ion levels on the color scale. $B$, Histogram of amplitudes of changes in the ratio of $340 / 380$ signals in response to the first QA application compared between opt/opt ( $n=4$ animals), opt $/+(n=1)$, opt $/ \mathrm{Mi}^{\mathrm{wh}}(n=7)$, and $+/+$ $(n=2)$ pups. Numbers above SE bars are the number of neurons. The number of $+/+$ and $o p t /+$ mice is limited, because they are produced only through recombination in the $o p t / M i^{\mathrm{wh}}$ intercross. $C$, Comparison of successive QA responses plotted relative to the intensity changes for the first response of each genotype [opt/opt $(n=4)$, opt $/+(n=$ $1)$, opt $/ \mathrm{Mi}^{\mathrm{wh}}(n=7$ and 3 for second and third response, respectively), and $+/+(n=$ $2)$. All genotypes were significant at $>0.01$ level compared with opt homozygotes. slices drifted toward higher values, as seen in Figure $7 A$. The data from numerous opt/opt, opt $/+$, opt $/ M i^{\mathrm{wh}}$, and $+/+$ Purkinje neurons are summarized in Figure $7 B, C$. Although $\mathrm{IP}_{3} \mathrm{R} 1$ protein expression is reduced in opt homozygote cerebellum, QA application is able to generate an initial calcium response from opt Purkinje neurons that is only moderately reduced from that seen in $+/+$ mice, with pups carrying only one opt allele responding in an intermediate fashion (Fig. $7 B$ ). In addition, the calcium response in opt homozygotes consistently shows less attenuation to repeated QA application than in $+/+$ mice, with opt heterozygotes $\left(o p t /+\right.$ and $\left.o p t / M i^{\mathrm{wh}}\right)$ again generating intermediate values (Fig. $7 C$ ).

\section{DISCUSSION}

By using two independent genetic analyses we have shown that opt is tightly linked to the $\mathrm{IP}_{3} \mathrm{R} 1$ gene on distal mouse chromosome 6 , making $\mathrm{IP}_{3} \mathrm{R} 1$ a candidate locus for the opt mutation. Northern blot analysis demonstrated that relative to controls, the size of the $\mathrm{IP}_{3} \mathrm{R} 1$ transcript in opt mice was reduced. Detailed primary structure analysis revealed that all of the $\mathrm{IP}_{3} \mathrm{R} 1$ transcripts recovered from opt brain RNA lacked a 324 nt region encoding 108 amino acids positioned within the putative transducing/modulatory domain of the $\mathrm{IP}_{3} \mathrm{R} 1$ protein. Western blot analysis confirmed this deletion and showed that the ORF had not been interrupted, although the altered $\mathrm{IP}_{3} \mathrm{R} 1$ protein was present at markedly reduced levels in the opt mice. These data clearly demonstrate that the $\mathrm{IP}_{3} \mathrm{R} 1$ transcript and protein are altered in opt.

The underlying cause of the altered $\mathrm{IP}_{3} \mathrm{R} 1$ protein in opt was shown to be $\mathrm{a}>10 \mathrm{~kb}$ genomic deletion that removes two exons ( $\mathrm{B}$ and $\mathrm{C}$ ) from the opt $\mathrm{IP}_{3} \mathrm{R} 1$ locus. This deletion occurs immediately $3^{\prime}$ of a region called SII, which produces a number of alternatively splicing transcripts in the wild-type $\mathrm{IP}_{3} \mathrm{R} 1$ gene $(\mathrm{Na}$ - 
kagawa et al., 1991). Our sequence analysis of intron/exon junctions (Fig. 5D) shows that splices in the SII region occur at phase 0; i.e., the exons are spliced between codons (Sharp, 1981), allowing all combinations of exon inclusion. Furthermore, we show that the glutamine residue, called SIIB by Nakagawa et al. (1991), is contiguous with exon $\mathrm{A}$, the glutamine codon providing a second $3^{\prime}$ acceptor site at that junction while maintaining the phase 0 reading frame. Finally, the observation that exon $\mathrm{D}$ is also phase 0 allows each of the alternate $5^{\prime}$ donor sites from the SII region to form uninterrupted translational frames in opt transcripts. Although matching of reading frames around the opt deletion is fortuitous, phase 0 introns have been shown to occur more often than phase 1 or 2 introns, with frequencies of $48 \%, 30 \%$, and $22 \%$, respectively, in a sample of 11,117 mammalian introns analyzed (Long et al., 1995). Thus the fact that the opt deletion begins and ends within intronic regions statistically favors the possibility of a maintained ORF, in this case permitting the opt allele to produce an altered but potentially functional $\mathrm{IP}_{3} \mathrm{R} 1$ protein.

Using a cerebellar slice preparation, we found that despite markedly reduced $\mathrm{IP}_{3} \mathrm{R} 1$ protein levels in opt, a strong calcium release from intracellular stores can still be elicited in Purkinje neurons, with the calcium response showing less attenuation to repeated QA application in opt homozygotes compared with that in littermates. How might this physiological phenotype result from deletion of exons $\mathrm{B}$ and $\mathrm{C}$ of the $\mathrm{IP}_{3} \mathrm{R} 1$ protein? One possible explanation is that the opt deletion, occurring in the cytoplasmic transducing domain, alters tertiary and quarternary protein structure in a region thought to couple the amino-terminal $\mathrm{IP}_{3}$-binding domain with the C-terminal calcium channel domain, thereby affecting the activation, conductance, or gating properties of the $\mathrm{IP}_{3} \mathrm{R} 1$ channel in opt. These possibilities could be addressed directly by studies at the single-channel level. Conformational changes in the opt $\mathrm{IP}_{3} \mathrm{R} 1$ protein might also affect the ability of accessory proteins such as calreticulin (Enyedi et al., 1993) and FK506-binding protein (Cameron et al., 1995) to complex with $\mathrm{IP}_{3} \mathrm{R} 1$ in $o p t$, thus altering normal channel regulation. In addition to deletion-induced conformational changes, the removal of a specific modulatory site for phosphorylation by PKA and GKA might contribute to the physiological phenotype of opt. The deletion in opt removes serine-1755, which is phosphorylated by GKA and PKA, leaving only serine-1588 available for PKA phosphorylation in opt homozygotes. This change in PKA phosphorylation site availability may alter the physiological outcome of phosphorylation on channel structure or function (Bezprozvanny and Ehrlich, 1995). Finally, because $\mathrm{IP}_{3} \mathrm{R} 1$ is reduced in opt, the change in the ratio of $\mathrm{IP}_{3} \mathrm{R} 1$ to other $\mathrm{IP}_{3} \mathrm{R}$ subtypes and to other proteins that regulate the calcium balance across the endoplasmic reticulum membrane, such as the calcium pump, luminal calciumbinding molecules, and other luminal and cytosolic accessory proteins, may affect the normal regulation of calcium uptake, storage, and mobilization (Taylor and Traynor, 1995), thereby changing the properties of release from $\mathrm{IP}_{3}$-sensitive calcium stores. In sum, the physiological phenotype seen in the $\mathrm{P} 4$ cerebellar Purkinje neurons of opt mice could be a consequence of reduced $\mathrm{IP}_{3} \mathrm{R} 1$ receptor number, conformational changes resulting from the deletion, and/or removal of specific modulatory sites from the $\mathrm{IP}_{3} \mathrm{R} 1$ protein.

The visible seizure phenotype displayed by opt begins $\sim 2$ weeks after birth, which coincides with the formation of synapses between Purkinje cells and parallel fibers of the granule cells (Altman, 1972), and prominent expression of $\mathrm{IP}_{3} \mathrm{R} 1 \mathrm{mRNA}$ (Furuichi et al., 1993) and protein (Maeda et al., 1989) in the cerebellum of wild-type mice, specifically in the somata and dendritic arbors of the Purkinje neurons (Ryo et al., 1993). Although we cannot formally exclude the possibility that a second tightly linked gene mutation might also contribute to the phenotype of opt, data presented here strongly suggest that alteration of the $I_{3} R 1$ protein is likely to be the primary deficit responsible for the physiological and behavioral changes seen in opt.

\section{REFERENCES}

Altman J (1972) Postnatal development of the cerebellar cortex in the rat. J Comp Neurol 145:399-464.

Berridge MJ (1993) Inositol trisphosphate and calcium signalling. Nature 361:315-325.

Bettler B, Boulter J, Hermans-Borgmeyer I, O'Shea-Greenfield A, Deneris ES, Moll C, Borgmeyer U, Hollmann M, Heinemann S (1990) Cloning of a novel glutamate receptor subunit, GluR5: expression in the nervous system during development. Neuron 5:583-595.

Bezprozvanny I, Ehrlich BE (1995) The inositol 1,4,5-trisphosphate $\left(\mathrm{InsP}_{3}\right)$ receptor. J Membr Biol 145:205-216.

Cameron AM, Steiner JP, Roskams AJ, Ali SM, Ronnett GV, Snyder SH (1995) Calcineurin associated with the inositol 1,4,5-trisphosphate receptor-FKBP12 complex modulates calcium flux. Cell 83:463-472.

Chomczynski P, Sacchi N (1987) Single-step method of RNA isolation by acid guanidinium thiocyanate-phenol-chloroform extraction. Anal Biochem 162:156-159.

De Smedt H, Missiaen L, Parys JB, Bootman MD, Mertens L, Van Den Bosch L, Casteels R (1994) Determination of relative amounts of inositol trisphosphate receptor mRNA isoforms by ratio polymerase chain reaction. J Biol Chem 269:21691-21698.

Enyedi P, Szabadkai G, Krause KH, Lew DP, Spat A (1993) Inositol 1,4,5-trisphosphate binding sites copurify with the putative Ca-storage protein calreticulin in rat liver. Cell Calcium 14:485-492.

Ferris CD, Cameron AM, Bredt DS, Huganir RL, Snyder SH (1991) Inositol 1,4,5-trisphosphate receptor is phosphorylated by cyclic AMPdependent protein kinase at serines 1755 and 1589. Biochem Biophys Res Commun 175:192-198.

Furuichi T, Mikoshiba K (1995) Inositol 1,4,5-trisphosphate receptormediated calcium signaling in the brain. J Neurochem 64:953-960.

Furuichi T, Yoshikawa S, Mikoshiba K (1989a) Nucleotide sequence of cDNA encoding $\mathrm{P}_{400}$ protein in the mouse cerebellum. Nucleic Acids Res 17:5385-5386.

Furuichi T, Yoshikawa S, Miyawaki A, Wada K, Maeda N, Mikoshiba K (1989b) Primary structure and functional expression of the inositol 1,4,5-trisphosphate-binding protein $\mathrm{P}_{400}$. Nature 342:32-38.

Furuichi T, Simon-Chazottes D, Fujino I, Yamada N, Hasegawa M, Miyawaki A, Yoshikawa S, Guenet J-L, Mikoshiba K (1993) Widespread expression of inositol 1,4,5-trisphosphate receptor type 1 gene (Insp3r1) in the mouse central nervous system. Receptors Channels $1: 11-24$.

Green EL (1981) Brother-sister inbreeding with heterozygosity forced by intercrosses (system 6). In: Genetics and probability in animal breeding experiments, pp 155-157. London: Macmillan.

Grobman AB, Charles DR (1947) Mutant white mice: a new dominant autosomal mutant affecting coat color in Mus musculus. J Hered 38:381-384.

Hodgkinson CA, Moore KJ, Nakayama A, Steingrimsson E, Copeland NG, Jenkins NA, Arnheiter H (1993) Mutations at the mouse microphthalmia locus are associated with defects in a gene encoding a novel basic-helix-loop-helix-zipper protein. Cell 74:395-404.

Katz LC (1987) Local circuitry of identified projection neurons in cat visual cortex brain slices. J Neurosci 7:1223-1249.

Komalavilas P, Lincoln TM (1994) Phosphorylation of the inositol 1,4,5trisphosphate receptor by cyclic GMP-dependent protein kinase. J Biol Chem 269:8701-8707.

Lane PW (1972) New mutants and linkages: opisthotonos (opt). Mouse News Lett 47:36.

Lin DD (1995) Expression and characterization of two alternatively spliced isoforms of rat type 1 receptor for inositol 1,4,5-trisphosphate. In: Physiology. Baltimore: The Johns Hopkins University School of Medicine.

Llano I, Dreessen J, Kano M, Konnerth A (1991) Intradendritic release of calcium induced by glutamate in cerebellar Purkinje cells. Neuron 7:577-583. 
Lock LF, Gilbert DJ, Street VA, Migeon MB, Jenkins NA, Copeland NG, Tempel BL (1994) Voltage-gated potassium channel genes are clustered in paralogous regions of the mouse genome. Genomics 20:354-362.

Long M, Rosenberg C, Gilbert W (1995) Intron phase correlations and the evolution of the intron/exon structure of genes. Proc Natl Acad Sci USA 92:12495-12499.

Maeda N, Niinobe M, Inoue Y, Mikoshiba K (1989) Developmental expression and intracellular location of $\mathrm{P} 400$ protein characteristic of Purkinje cells in the mouse cerebellum. Dev Biol 133:67-76.

Manly KF (1993) A Macintosh program for storage and analysis of experimental genetic mapping data. Mamm Genome 4:303-313.

Matsumoto M, Nakagawa T, Inoue T, Nagata E, Tanaka K, Takano H, Minowa O, Kuno J, Sakakibara S, Yamada M, Yoneshima H, Miyawaki A, Fukuuchi Y, Furuichi T, Okano H, Mikoshiba K, Noda T (1996) Ataxia and epileptic seizures in mice lacking type 1 inositol 1,4,5trisphosphate receptor. Nature 379:168-171.

Mignery GA, Newton CL, Archer III BT, Sudhof TC (1990) Structure and expression of the rat inositol 1,4,5-trisphosphate receptor. J Biol Chem 265:12679-12685.

Nakagawa T, Okano H, Furuichi T, Aruga J, Mikoshiba K (1991) The subtypes of the mouse inositol 1,4,5,-trisphosphate receptor are expressed in a tissue-specific and developmentally specific manner. Proc Natl Acad Sci USA 88:6244-6248.

Padgett RA, Grabowski PJ, Konarska MM, Seiler S, Sharp PA (1986) Splicing of messenger RNA precursors. Annu Rev Biochem 55:1119-1150.

Pin JP, Duvoisin R (1995) The metabotropic glutamate receptors: structure and functions. Neuropharmacology 34:1-26.

Ryo Y, Miyawaki A, Furuichi T, Mikoshiba K (1993) Expression of the metabotropic glutamate receptor mGluR $1 \alpha$ and the ionotropic glutamate receptor GluR1 in the brain during the postnatal development of normal mouse and in the cerebellum from mutant mouse. J Neurosci Res 36:19-32.

Sharp PA (1981) Speculations on RNA splicing. Cell 23:643-646.

Steingrimsson E, Moore KJ, Lamoreux ML, Ferre-D'Amare AR, Burley SK, Sanders Zimring DC, Skow LC, Hodgkinson CA, Arnheiter H, Copeland NG, Jenkins NA (1994) Molecular basis of mouse microphthalmia $(\mathrm{mi})$ mutations helps explain their developmental and phenotypic consequences. Nature Genet 8:256-263.

Street VA, Robinson LC, Erford SK, Tempel BL (1995) Molecular genetic analysis of distal mouse chromosome 6 defines gene order and positions of the deafwaddler and opisthotonos mutations. Genomics 29:123-130.

Street VA, Hopkins WF, Tempel BL (1996) Genomic structure, sequence, and physiological expression of mKv1.5, a mouse potassium channel gene. Epilepsy Res [Suppl] 12:165-175.

Tassabehji M, Newton VE, Read AP (1994) Waardenburg syndrome type 2 caused by mutations in the human microphthalmia (MITF) gene. Nature Genet 8:251-255.

Taylor CW, Traynor D (1995) Calcium and inositol trisphosphate receptors. J Membr Biol 145:109-118.

Xiang L, Werner D (1989) The complete cDNA sequence of mouse elongation factor 1 alpha (EF1 alpha) mRNA. Nucleic Acids Res 17:442.

Yamada N, Makino Y, Clark RA, Pearson DW, Mattei M-G, Guenet J-L, Ohama E, Fujino I, Miyawaki A, Furuichi T, Mikoshiba K (1994) Human inositol 1,4,5-trisphosphate type-1 receptor, $\operatorname{Ins}_{3} \mathrm{R} 1$ : structure, function, regulation of expression and chromosomal localization. Biochem J 302:781-790.

Yuzaki M, Mikoshiba K (1992) Pharmacological and immunocytochemical characterization of metabotropic glutamate receptors in cultured Purkinje cells. J Neurosci 12:4253-4263. 